Ана Римар Симуновић

Универзитет у Новом Саду

Филозофски факултет

Одсек за русинистику

anarsimunovic@ff.uns.ac.rs
УДК 821.161.2.09"19"

https://doi.org/10.18485/slavistika.2020.24.2.28

оригинални научни рад

примљено 20.03.2020.

прихваћено за штампу 18.09.2020.

\title{
УКРАЈИНА У АУТОРСКОМ МИТУ МИХАЈЛА КОВАЧА*
}

У овом раду ћемо показати како Ковач представља Украјину као завичај Русина у најширем смислу у свом миту завичаја. Анализираћемо Ковачева књижевна дела и дневнике, који чине саставни део његовог опуса, у којима инсистира на тези да су Русини део украјинског народа, па тако и русинску књижевност сагледава као органски део украјинске књижевности. Посебну пажњу посветићемо оним фрагментима дневника који сведоче о Ковачевом погледу на питања као што су идентитет Русина, њихов однос према својој традицији, вери и култури, као и о односу Русина према Украјини.

Кључне речи: мит, завичај, Михајло Ковач, украјинска књижевност, русинска књижевност.

This paper shows how Kovač in his homeland myth depicts Ukraine as the homeland of the Ruthenians in the broadest sense. Kovač's literary works and diaries are analysed, which form the fundamentals of his oeuvre, and in which he maintains that Ruthenian literature is an organic part of Ukrainian literature. Special attention is paid to the diary fragments which bear testimony to Kovač's view on questions such as Ruthenian identity, their relation to their tradition, faith and culture, as well as their relation to Ukraine.

Keywords: myth, homeland, Mihajlo Kovač, Ruthenian literature, Ukrainian literature.

Михајло Ковач, истакнут русински писац, своје књижевно дело формирао је под утицајем класика украјинске књижевности. Основа на којој је Ковач изградио своје дело је матрица ауторског мита Украјине Тараса Шевченка, коју је Ковач преузео и на основу ње изградио свој мит русинског завичаја. Као што ни код Шевченка Украјина не представља конкретно место или територију, већ начин постојања (Грабович 1991: 67), тако је и код Ковача завичај комплекснији појам. Завичај код Ковача означава завичај у ужем смислу, а то значи завичај који се креће од родног дома, који представља једини простор среће у Ковачевим делима и уједно је космогонијски симбол, преко села у којем се дом налази, до завичаја у ширем смислу, који се односи на отаџбину, односно Украјину, одакле су се Русини доселили и одакле носе свој језик, веру и традицију. У овом раду ћемо показати како Ковач представља Украјину као завичај Русина у најширем смислу у свом миту завичаја. Анализираћемо

* Овај рад је део истраживања у оквиру пројекта Дискурси мањинских језика и књижевности у југоисточној и средњој Европи (178017) који финансира Министарство просвете, науке и технолошког развоја Републике Србије. Рад представља део истраживања у оквиру израде докторске дисертације на докторским студијама језика и књижевности на Филозофском факултету у Новом Саду, под менторством проф. др Људмиле Поповић. 
Ковачева књижевна дела и дневнике ${ }^{1}$, који чине саставни део његовог опуса, у којима инсистира на тези да су Русини део украјинског народа, па тако и русинску књижевност сагледава као органски део украјинске књижевности. Посебну пажњу посветићемо оним фрагментима дневника који сведоче о Ковачевом погледу на питања као што су идентитет Русина, њихов однос према својој традицији, вери и култури, као и о односу Русина према Украјини. Треба нагласити да Јулијан Тамаш, русиниста и украјиниста, украјинску књижевност сматра матичном за русинску књижевност. Русинистика се данас види као посебна дисциплина, тада најчешће оптерећена функцијом јачања националне или народне посебности, али се види и у украјинистици и као регионална традиција (Тамаш 2008: 38).

У путописном есеју Дияспора (Ковач 1992) Ковач описује свој одлазак у старе крајеве и бележи сведочење о животу Русина у крајевима Мађарске, Хрватске, Украјине, које је том приликом посетио:

„Изгледа да нема народа који има толико „старих крајева” и толико имена као што их има моја народност. Не сметају ми толика имена, ни толике отаџбине, смета ми само свађа, мржња и себичност, тога је било, тога ту и тамо још увек има. Смета ми што људи од дрвећа не виде шуму, што не виде очигледну истину - нема детета које мајку нема... Нисам кренуо на пут да тражим отаџбину, већ да се сретнем са крајем и људима који су остали на етапи спуштања из још старијег нашег старог краја" (Ковач 1992: 6). ${ }^{2}$

Значај овог путописа огледа се и у експлицитним Ковачевим изјавама о питањима националног идентитета Русина, као и о томе да Украјину види као своју отаџбину, али и као отаџбину својих сународника. За себе каже да је његов крај сада „тамо око Дунава”, а да путеви до отаџбине Русина воде „кроз угарску крајину, преко Карпата, кроз галицијско-волинску државу, РУСКУ државу3, која је постојала близу 300 година" (Ковач 1992: 13). Ковач наводи да је циљ овог пута упознавање људи и околности Русина у тим селима, прикупљање етнографског и историјског материјала. Осим тога, један од циљева је и успостављање веза са Русинима који су се у тзв. секундарној сеоби, током 19. века, селили из Руског Крстура и Куцуре у Срем и Славонију. ${ }^{4}$ У тим селима само припадници старије генерације говоре русински, а припадницима млађе генерације русински језик већ је стран. Разлоге таквог стања Ковач види у неодржавању веза са селима из којих су се доселили, јер су „окружени туђим народом, одсечени од свог корена, усамљени, заборавили на свој народ

${ }^{1}$ Ковачеви дневници су део наслеђа које чува Олга Карлаварис, његова ћерка. Захваљујемо joj што нам је за потребе научног истраживања дала на коришћење дневнике свог оца.

${ }^{2}$ Сви наведени цитати из Ковачевих књижевних дела и дневника у оригиналу су објављени односно написани на русинском језику. За потребе овог рада преведени су на српски језик.

3 „Украјинска историографија разликује појмове $Р y с$ и Росія те одговарајуће придеве: рускьийросійський. Први се односи на РусинеУкрајинце у Западној Украјини, под другим се подразумева каснија московска односно руска држава" (Zukovskij i dr. 2018: 279).

${ }^{4}$ „Тражећи земљу и лакше услове за живот, од самог почетка XIX века кренуо је талас организованог исељавања многих породица из Крстура и Куцуре у више насеља у Бачкој и Срему "(Рамач 2007: 195). 
и своје порекло” (Ковач 1992: 26). Међутим, он сматра да се не треба препустити асимилацији: „Пропада онај народ и онај човек који изгуби веру у себе и у своје снаге. А наши Русини кроз 200 година у тешким условима нису изгубили веру у себе, нису се стидели оног што су од прадедова наследили" (Ковач 1992: 32).

Да је Ковач кроз своја књижевна дела желео да охрабрује своје сународнике у очувању језика и националног идентитета, сведочи и напис из дневника 1970. године: „Пишем са тенденцијом да код Русина подигнем веру у себе, да га научим да поштује и воли свог оца и своју мајку, а с њима и свој народ"5

У дневнику из исте године Ковач детаљно пише о неслагањима са русинским писцима и културним радницима по питању националног идентитета Русина, јер су они одрицали било какву везу русинског језика са украјинским, као и Русина са Украјином, а Ковач је управо ту везу сматрао суштинском за опстанак и даљи развој, како Русина, тако и русинског језика: „Шта се дешава са стаблом којем одсечемо корење? Наш говор не може се развијати без те везе са својим основним кореном."6 Основним кореном русинског језика Ковач сматра украјински језик:

„Украјински језик је потребан за русински колико и грожђе за вино. Ко ми тврди или ко ради тако да прави, развија русински језик без познавања украјинског, тај прави вино без грожђа. Не тврдим да тако вина нема, али тврдим да је оно - неприродно."7

У путопису Дияспора такође експлицитно наводи да сматра да русински језик вуче корене из украјинског језика: „Наш језик има свој корен у језику једног 45 милионског народа" (Ковач 1992: 32-33).

У Ковачевим дневницима много је експлицитних изјава о томе да русински народ види као део украјинског народа, а овде ћемо навести најзначајније:

- „У сопственом дому сопствене власти би другачије радиле; децу и народ би упознале са њиховом прошлошћу, њиховом културом, њиховим језиком, изучиле би друштвене кадрове, дали их на места где треба науци светло палити и Русин би био свестан Украјинац, а истовремено и син ове земље у којој се родио и где живи." 8

- „Једино што желим је да наши писци, научни и културни радници сами уче и продубљују знање украјинског језика, културе и књижевности. Нека пишу, нека буду и даље тврди Русини, као Ковач, нека развијају „у зноју лица свог” ово овде наше, али имајући пред очима, не само у теорији, да је наша књижевност део украјинске књижевности."9

- „Ја сам Југословен према нахођењу, али не и према пореклу. Ја сам за неговање матерњег језика, овог, русинског, али истовремено сам и за

\footnotetext{
${ }^{6}$ Ковач, Дневник 1970, стр. 233

${ }^{7}$ Ковач, Дневник 1970, стр. 203

${ }^{8}$ Ковач, Дневник 1970, стр. 288

${ }^{9}$ Ковач, Дневник 1967, стр. 429

${ }^{9}$ Ковач, Дневник 1969, стр. 515
} 
неговање љубави према народу од ког потичемо. И не сматрам да ћу због тога мање волети југословенске народе и друштво у којем живим."10

- „Изолација од матичног народа је опасна јер прети или асимилацији са средином у којој живи или прикључивањем оној народности са којом има највише сличности после украјинске." 11

- „План писања је овакав: I „Туђина”

1) приповетка би морала да има око 40 страна

2) обухватила би крај и животни пут једног од оних који су долутали из гора у равницу

3) садржај - глобално: стари крај - лутање - примошћавање - смрт

4) Идеја: тиха почаст меком Русину који је до краја живота остао тврд само према себи, који је био у стању да уради све, осим да одбаци и да се одрекне свог имена, свог народа и не оног малог русинског народа, већ оног великог, славног, који је њему, несвесном, дао своје карактеристике. Русин то не зна, али он то има, он то носи у себи, он се по томе познаје." 12

Није познато да је приповетка под овим насловом и са свим овде наведеним идејама објављена. Међутим, идеја коју је овде Ковач представио препознаје се у многим његовим приповеткама. Знајући да је наведене проблеме око националног идентитета Русина Ковач литераризовао у својим књижевним делима, али и додајући нов поглед на целокупно књижевно дело, посматрајући га кроз призму наведеног плана писања, можемо да закључимо да је управо у овом плану Ковач изнео нацрт ауторског мита завичаја.

Храбович је указао на то да у Украјини Шевченковог мита делује митолошко време, а не историјско, и поделио га је у три стадијума. Далеко прошло и будуће време представљају време хармоније, време Златног века, које је у Украјини некад давно владало и у које ће се она вратити. Средњи стадијум, којем припада недавно прошло и савремено доба представља главни предмет Шевченкове пажње и ово време представља свет дубоке дисхармоније (Грабович 1991: 158-159). Ова три стадијума уочавамо и у Ковачевом миту. Давно прошло време код Ковача би било време првих генерација досељеника Русина из Украјине, коју Ковач види као отаџбину Русина, на просторе тадашње јужне Угарске. У том времену које код Ковача можемо препознати као Златно доба, видимо да је то време у ком су припадници русинског народа поштовали своју традицију, веру, језик, порекло и у ком су били свесни да су дошли из Украјине: „У духу те везаности за стари руски народ и стару руску виру ${ }^{13}$ наш је човек живео, а то значи да се држао вере и обичаја које је наследио од својих старих. Он припада веома великом народу и ту своју „државност” носио са собом тамо где се насељавао” (Ковач 1992: 221). Овај стадијум у Ковачевом миту можемо препознати и као егзистенцијалну

${ }^{10}$ Ковач, Дневник 1969, стр. 529

${ }^{11}$ Ковач, Дневник 1969, стр. 654

${ }^{12}$ Ковач, Дневник 1970-75, стр. 145

${ }^{13}$ На овом месту Ковач такође користи придев руски у значењу које се у украјинској историографији користи када се мисли на Русине односно Украјинце у западној Украјини. 
категорију у садашњем времену, јер овом стадијуму припадају и припадници старије генерације.

Садашње време би, као и код Шевченка, било време дисхармоније, нарушеног друштвеног поретка. То је такође време које представља центар Ковачевог интересовања, а у којем су присутне опозиције између припадника старије генерације, који још увек поштују традицију ${ }^{14}$, и припадника млађе генерације, који не виде значај у очувању свог језика и традиције. Разлоге такве ситуације Ковач види у номадској судбини Русина:

„Било је потребно прво задовољити физичку глад, а тек онда мислити на духовну" (Ковач 1992: 219). Све слабије развијен осећај припадности русинском, а тиме и украјинском народу, Ковач види у проклетству самодоказивања пред другима у борби за опстанак:

„То проклетство самодоказивања пред другима ми носимо из времена кад смо се раселили по целом свету" (Ковач 1987: 64).

У приповеци Вона єдина Ковач у центар поставља брачни пар који се из Бачке сели у Славонију. Њихову судбину изједначава са номадском судбином многих Русина, као и да Украјину види као њихов завичај у најширем смислу:

„Ми смо вечне луталице, народ бездоман, деца која су због некаквог проклетства, пре стотине година откинута из подољских пространстава, прешла преко леђа Карпата на величанствену Словенску степу, која је пригрлила оне који су били најсмелији, а они су опет почели да лутају по степама Панонске равнице, опет су прелазила реке и шуме да би се зауставили на водама и шумама словенским и под горама босанским... Лутали смо тражећи место на грудима мајке земље" (Ковач 1970: 31).

Ковач се у својим књижевним делима непрестано враћа у време (првих) предака, који су били свесни свог порекла. Дом предака, али и припадника старије генерације, представља сакрални простор. То је место где се учи матерњи језик и где се стиче осећај националног идентитета, а тиме и свог порекла. Такав дом представља центар света, наспрам неуређеног хаоса изван тог дома. Мирча Елијаде наводи да човек премодерних друштава смисао свог постојања види у усмеравању свог живота према центру света, односно космосу. У Ковачевом миту видимо да млади више не доживљавају дом као космос, он је за њих изгубио сакрално значење и због тога они припадају хаосу и времену дисхармоније. Настањивање новог простора, за религиозног човека ${ }^{15}$ према Елијадеу подразумева сакрализовање тог места односно понављање космогоније (Елијаде 2003: 84-85):

„Настанити се на једној територији то у крајњем случају значи сакрализовати је. Када то настањивање није привремено, као код номада, већ стално, оно подразумева једну виталну одлуку, која обавезује егзистенцију целокупне заједнице. „Сместити се” на једном месту, организовати га, настанити - то зна-

${ }^{14}$ „А традиција је, видели смо, име, и језик, и вера и обичаји и духовно наслеђе које се чува у памћењу народном, али и у историји записано" (Ковач 1992: 219).

${ }^{15}$ Према Елијадеу, религиозни човек је човек за којег космос представља сакрални простор у оквиру заједнице којој припада и која живи тај мит. 
чи извести низ чинова који претпостављају један егзистенцијални избор: избор Универзума, до кога се долази „стварајући” га” (Елијаде 2003: 85).

У својим делима Ковач позива на поновно стварање света, тј. поновно успостављање космоса, који се у свету који Ковач описује у својим делима губи, како у свакој следећој генерацији Русина, тако и селидбом Русина у места у којима нису организовани и у којима предстаљају мањину. Понављање космогоније једини је начин на који је могуће очувати егзистенцију русинске заједнице, својим митом поручује Ковач. Кружно време, односно враћање на почетак, код Ковача се односи на свест о припадности родном дому, али и шире, на свест о својим коренима у отаџбини, односно у Украјини. Будуће време, тј. пројекција златног доба у будућности, могло би се код Ковача дефинисати као време у којем русински народ ускрсава након освешћивања о Украјини као својој отаџбини. Тиме је заокружен Ковачев мит у којем влада кружно време.

\section{Цитирана литература}

Грабович, Григорій. Шевченко як міфотворець. Київ: Радянський письменник, 1991.

[Grabovič, Grigorij. Ševčenko âk mifotvorec'. Kiïv: Radâns'kij pis'mennik, 1991]

Елијаде, Мирча. Свето и профано. Нови Сад, Сремски Карловци: Издавачка књижарница Зорана Стојановића, 2003.

[Elijade, Mirča. Sveto i profano. Novi Sad, Sremski Karlovci: Izdavačka knjižarnica Zorana Stojanovića, 2003]

Рамач, Јанко. Русини у Јужној Угарској (1745-1918). Нови Сад: Војвођанска академија наука и уметности, 2007.

[Ramač, Janko. Rusini u Južnoj Ugarskoj (1745-1918). Novi Sad: Vojvođanska akademija nauka i umetnosti, 2007]

Tamaš, Julijan. Veličina malih, poetika regionalnih i malih književnih tradicija. Novi Sad: Vojvođanska akademija nauka i umetnosti, 2008.

Žukovskij, Arkadij i dr. Kratka istorija Ukrajine. Beograd: Dan graf, 2018.

\section{Извори}

Ковач, Михайло. Цихи води. Нови Сад: Руске слово, 1970.

[Kovač, Michajlo. Cichi vodi. Novi Sad: Ruske slovo, 1970]

Ковач, Михайло. Глїбоки коренї. Нови Сад: Руске слово, 1987.

[Kovač, Michajlo. Hljiboki korenji. Novi Sad: Ruske slovo, 1987]

Ковач, Михайло. Дияспора, драгопис и историйни есей. Нови Сад: Руске слово, 1992.

[Kovač, Michajlo. Dijaspora, drahopis i istorijni esej. Novi Sad: Ruske slovo, 1992] 


\title{
Необјављени извори
}

\author{
Дневници Михајла Ковача: \\ Дневник 1967 \\ [Dnevnik 1967] \\ Дневник 1969 \\ [Dnevnik 1969] \\ Дневник 1970 \\ [Dnevnik 1970] \\ Дневник 1970-75 \\ [Dnevnik 1970-75]
}

\section{Ana Rimar Simunović}

\section{UKRAINE IN MIHAJLO KOVAČ'S MYTH}

\begin{abstract}
Summary
The foundation on which Kovač has built his work is the matrix from Taras Shevchenko's myth of Ukraine, which Kovač used as a basis for creating his own Ruthenian homeland myth. Like in Shevchenko's myth, where Ukraine represents a mode of existence rather than a specific place or teritory, Kovač's homeland is also a complex term. Kovač's homeland denotes the homeland in various senses, starting from the childhood home, which is both the only place of happiness and a cosmogonic symbol in his works. It ranges through the home village, to the homeland in a broader sense, where it refers to the fatherland, or Ukraine, the place where the Ruthenians moved from and where their language, faith and tradition originate from. This paper shows how Kovač in his homeland myth depicts Ukraine as the homeland of the Ruthenians in the broadest sense. Kovač's literary works and diaries are analysed, which form the fundamentals of his oeuvre, and in which he maintains that the Ruthenians are part of the Ukrainian people. Consequently, he sees Ruthenian literature as an organic part of Ukrainian literature. Special attention is paid to the diary fragments which bear testimony to Kovač's view on questions such as Ruthenian identity, their relation to their tradition, faith and culture, as well as their relation to Ukraine.

Keywords: myth, homeland, MihajloKovač, Ruthenian literature, Ukrainian literature.
\end{abstract}

